\title{
OPTIMALISASI SEKTOR PARIWISATA GUNA MENINGKATAN PENDAPATAN ASLI DESA (PADes)
}

(Studi Kasus Pulau Kenawa di Desa Poto Tano Kecamatan Poto Tano Kabupaten Sumbawa Barat)

\section{OPTIMIZATION OF THE TOURISM SECTOR TO INCREASE ORIGINAL VILLAGE INCOME (PADES)}

(Case Study of Kenawa Island in Poto Tano Village, Poto Tano District, West Sumbawa Regency)

\author{
Yudhi Lestanata1, ${ }^{1}$ Iham Zitri² \\ 1,2 Ilmu Pemerintahan Universitas Muhammadiyah Mataram, Indonesia \\ E-mail: ilham.zitri@ummat.ac.id
}

\begin{abstract}
Human life is highly dependent on natural resources. Is the main and fundamental capital to meet the needs of human life. In this regard, optimizing the use of natural resources must be achieved by considering the potential aspects, conformity sustainability, and consistency, of the benefits to realize its sustainability. To achieve this optimization required the maintenance action at the point of normal balance. This study aims to find out how the role of Local Government in optimizing the potential of tourism in Kenawa Island and what are the factors inhibiting the optimization of toursm potential in Kenawa Island. This type of research is qualitative descriptive, taking the location in Poto Tano Village Poto Tano Village Poto Tano Sub-district, West Sumbawa Regency, data source in this research is primary data and secondary data. Based on the results of the research indicates that the optimization efforts undertaken by the Regional Government in developing the tourism potential of Kenawa Island are with community participation, environmental carrying capacity, promotion, involvement of all stakeholder, local ownership involvement, resource utilization continues, accommodating community aspirations, monitoring and program evaluation, environmental accountability, community training.
\end{abstract}

Keywords: Optimization, Tourism, Original Village Income

\begin{abstract}
ABSTRAK
Kehidupan manusia sangat tergantung pada sumber daya alam. Sumber daya alam merupakan modal utama dan fundamental untuk memenuhi kebutuhan kehidupan umat manusia. Berkaitan dengan hal tersebut, maka optimalisasi penggunaan sumber daya alam harus dicapai dengan mempertimbangkan aspek potensi, kesesuaian, kelestarian dan konsistensi manfaat untuk mewujudkan keberlanjutannya. Untuk mencapai optimalisasi ini diperlukan adanya tindakan pemeliharaan pada titik keseimbangan yang normal. Penelitian ini bertujuan untuk mengetahui bagaimana peran Pemerintah Daerah dalam mengoptimalisasikan
\end{abstract}

Journal of Governance and Local Politics (JGLP)

ISSN (online): 2684-9992, Volume: 2, Nomor: 1, Mei 2020 
potensi wisata di Pulau Kenawa serta apa saja yang menjadi faktor penghambat dalam optimalisasi potensi wisata di Pulau Kenawa. Jenis penelitian ini adalah deskriftif kualitatif, mengambil lokasi di Desa Poto Tano Kecamatan Poto Tano Kabupaten Sumbawa Barat, sumber data dalam penelitian ini adalah data primer dan data sekunder. Berdasarkan hasil penelitian menunjukkan bahwa upaya optimalisasi yang dilakukan oleh Pemerintah Daerah dalam mengembangkan potensi wisata Pulau Kenawa adalah dengan partisipasi masyarakat, daya dukung lingkungan, promosi, keterlibatan segenap pemangku kepentingan, keterlibatan kepemilikan lokal, pemanfaatan sumber daya berlanjut, mengakomodasi aspirasi masyarakat, monitor dan evaluasi program, akuntabilitas lingkungan, pelatihan pada masyarakat.

Kata kunci: Optimalisasi, Pariwisata, Pendapatan Asli Dasa

\section{PENDAHULUAN}

Kehidupan manusia sangat tergantung pada sumber daya alam. Sumber daya alam merupakan modal utama dan fundamental untuk memenuhi kebutuhan kehidupan umat manusia. Berkaitan dengan hal tersebut, maka optimalisasi penggunaan sumber daya alam harus dicapai dengan mempertimbangkan aspek potensi, kesesuaian, kelestarian dan konsistensi manfaat untuk mewujudkan keberlanjutannya1. Unkuk mencapai optimalisasi ini diperlukan adanya tindakan pemeliharaan pada titik keseimbangan yang normal.

Kabupaten Sumbawa Barat memiliki banyak wisata yang menarik untuk dikunjungi, salah satunya objek wisata Pulau Kenawa yang terletak di Desa Poto Tano Kecamatan Poto Tano Kabupaten Sumbawa Barat. Pulau Kenawa merupakan salah satu Pulau di gugusan Pulau Gili Balu yang mempunyai luas 13,8 ha dengan garis pantai yang membentang sepanjang 1,73 km. Daratan Pulau Kenawa didominasi oleh padang rumput yang hampir lebih dari sebagian luas pulau, vegetasi mangrove menutupi sekitar $1 / 4$ garis pantai.

Kabupaten Sumbawa Barat memiliki objek wisata yang sangat indah yaitu Pulau Kenawa. Pulau Kenawa merupakan salah satu pulau yang masih alami yang berada di kawasan Kabupaten Sumbawa Barat. Pulau Kenawa ini sangat menarik perhatian wisatawan khususnya wisatawan lokal. Wisatawan lokal tertarik dengan Pulau Kenawa dikarenakan Pulau Kenawa dikelilingi oleh pasir putih yang indah, di mana menyediakan pemandangan eksotis.

${ }^{1}$ D.I. Aceh, P. E. . K. Kewenangan Pengelolaan Sumber Daya Alam 
Dalam pengembangan objek wisata Pulau Kenawa, peran Pemerintah Kabupaten Sumbawa Barat, khususnya Pemerintah Desa Poto Tano sangatlah penting dalam pembangunan pariwisata guna meningkatkan kesejahteraan ekonomi masyarakat. Salah satunya dengan melakukan kegiatan promosi untuk menarik minat wisatawan untuk berkunjung ke lokasi wisata Pulau Kenawa. Sebagaimana yang kita ketahui dengan cara promosi wisatawan dapat mengetahui informasi perihal objek wisata tersebut.

Promosi dapat diharapkan dapat memberikan kontribusi positif bagi pengembangan ekonomi Kabupaten Sumbawa Barat khususnya Desa Poto Tano. Dalam menunjang kegiatan wisatawan, Pemerintah Kabupaten Desa Poto Tano menyediakan fasilitas penyewaan perahu milik masyarakat yang ada di dermaga untuk penyeberangan ke pulau dan ketika sampai di Pulau Kenawa wisatawan juga difasilitasi dengan saung. Dari sisi lain, Pulau Kenawa menyimpan sangat banyak keindahan, salah satunya keindahan padang savana yang hijau di musim hujan dan cokelat eksotis di musim kemarau serta keindahan pasir putihnya yang terhampar di sepanjang bibir pantai sangat cocok untuk kegiatan berjemur bagi para wisatawan. Bagi wiasatawan yang ingin mengeksplore seluruh keindahan Pulau Kenawa banyak kegiatan yang menarik yang bisa dilakukan di pulau ini yakni, melalukan snorkeling (menyelam) menikmati keindahan bawah laut Pulau Kenawa dan bagi wisatawan yang hobi mendaki, di Pulau Kenawa terdapat sebuah bukit yang bisa didaki oleh wisatawan untuk menyaksikan matahari terbenam (sunset).

Selain kegiatan mendaki bukit dan snorkeling, kegiatan berkemah di malam hari juga menjadi alternatif di pulai ini. Suasana saat malam begitu tenang karena memang Pulau ini tidak berpenghuni. Dalam hal ini, Pemerintah Desa Poto Tano harus lebih mengembangkan kegiatan pariwisata di Pulau Kenawa agar dapat memberikan dampak positif terhadap kondisi lingkungan fisik, kondisi ekonomi, sosial dan budaya masyarakat sekitar kawasan wisata tersebut, khususnya penduduk Desa Poto Tano .

Di sini sumber daya alam memiliki peran sebagai modal pertumbuhan ekonomi (resource based economy) dan sekaligus sebagai penopang sistem kehidupan (life support system). Oleh karena itu, sumber daya alam senentiasa harus dikelola secara seimbang untuk menjamin keberlanjutan pembangunan 
nasional, dan untuk sebesar-besarnya kemakmuran rakyat ${ }^{2}$. Atas dasar ini, maka sumber daya alam merupakan modal penting dalam menggerakkan roda pembangunan dan menjadi isu strategis dalam pelaksanaan pembangunan baik dalam konteks pembangunan negara, provinsi maupun kabupaten/kota.

Pulau Kenawa merupakan salah satu dari delapan pulau-pulau kecil yang dikenal dengan sebutan Gili Balu' yang berada bagian utara Desa Poto Tano Kecamatan Poto Tano. Pulau ini memiliki potensi yang sangat strategis untuk dijadikan sebagai lokasi wisata bahari. Selain memiliki keindahan dan panorama alam (mangrove dan pasir putih) juga memiliki keindahan alam laut dan ekosistemnya.

Pulau Kenawa berada di Desa Poto Tano Kecamatan Poto Tano Kabupaten Sumbawa Barat Provinsi Nusa Tengara Barat (NTB). Jaraknya dari pusat kota kurang lebih sekitar 20 kilometer, dengan durasi perjalanan sekitar 1 jam. Pulau Kenawa yang menjadi daya tarik wisatawan lokal karena memiliki panorama alam yang memesona, perpaduan alam perbukitan dan dikelilingi oleh pasir putih yang indah. Pulau Kenawa memiliki luas wilayah 13,8 hektar dan pulau ini tidak berpenghuni. Akses yang digunakan untuk menuju Pulau Kenawa menggunakan perahu nelayan, dan jaraknya tidak jauh, hanya butuh waktu tempuh selama 15 menit dari Pelabuhan Poto Tano. Untuk tarif normalnya 250 sampai 300 ribu sekali angkut dengan kapsitas 6 sampai 7 orang 3 .

Pulau Kenawa ini akan mempunyai nilai jual yang tinggi apabila bisa dikelola dengan baik. Akan tetapi Pulau Kenawa ini masih kurang diperhatikan oleh Pemerintah Daerah Kabupaten Sumbawa Barat, terutama dalam hal fasilitas yang tersedia di pulau ini. Sarana dan prasarana masih sangat minim yang dapat mengurangi minat atau daya tarik para wisatawan yang akan berwisata ke Pulau Kenawa.

Pemerintah Daerah khususnya Dinas Pariwisata masih belum optimal mengelola dan mengembangkan Pulau Kenawa. Sehingga masih sedikit sekali minat wisatawan asing berkunjung ke lokasi ini. Pulau Kenawa hanya mampu

\footnotetext{
2 La Fua, J. (2015). Manajemen Pemanfaatan Sumber Daya Alam di Indonesia untuk Mendukung Pembangunan Berkelanjutan Melalui Pendekatan Ekonomi Hijau. Shautut Tarbiyah, 21(1), 57-76.

${ }^{3}$ https://travel.kompas.com/read/2013/07/19/0913376/Pulau.Kenawa.Surganya.Sumbawa.?page=all 
menarik perhatian wisatawan lokal dan hanya sebagian kecil saja wisatawan mancanegara. Hal tersebut sangat disayangkan, karena dengan adanya sumber daya alam yang berkualitas dan mempunyai nilai jual yang tinggi, namun pemerintah daerah tidak bisa mengelolanya dengan baik dan optimal.

Kondisi kawasan Pulau Kenawa masih belum memberikan kepuasan kepada para pengunjung, misalnya bila meninjau sarana dan prasarana yang sangat minim. Tidak tersedianya sarana dan prasarana yang memadai pastinya akan mempengaruhi jumlah kunjungan pada masa yang akan datang. Berdasarkan latar belakang di atas adapun rumusan masalah yang diambil adalah sebagai berikut: Bagaimanakah peran Pemerintah dalam mengoptimalisasikan potensi wisata di Pulau Kenawa dalam optimalisasi potensi wisata di Pulau Kenawa

\section{METODE PENELITIAN}

Metode penelitian ini menggunakan pendekatan kualitatif, yaitu metode penelitian yang digunakan adalah penekanan pada observasi wawancara untuk pemerintah, sebagai lawannya adalah gambaran kondisi objektif secara ilmiah, di mana peneliti adalah instrument kunci. Teknik pengumpulan data dilakukan secara triangulasi (gabungan), analisis data bersifat induktif dan hasil penelitian kualitatif lebih menekankan makna dari pada generalisasi. Penempatan lokasi penelitian bagi penelitian ilmiah memang berbagai pertimbangan ilmiah maupun pertimbangan pertimbangan praktisnya. Pertimbangan ilmiahnya, apakah lokasinya tersebut terdapat masalah yang banyak dikaji secara ilmiah, bahwa objek tersebut adalah mudah dijangkau, efektif, dan efisien dari segi waktu dan biaya.

Untuk itu penelitian ini berlokasi di Desa Poto Tano (kawasan objek wisata Pulau Kenawa) dengan alasan penyusun memilih lokasi penelitian tersebut yaitu, penyusun tertarik untuk mengetahui peran Pemerintah dalam mengoptimalisasikan potensi wisata di Pulau Kenawa dalam optimalisasi potensi wisata di Pulau Kenawa guna Meningkatkan Pendapatan Asli Desa. Penelitian ini akan menggambarkan kondisi alamiah sesuai dengan fakta yang terjadi di lapangan yang berkaitan dengan Optimalisasi Sumber Daya Alam Menuju Ekowisata Guna Meningkatkan Pendapatan Asli Desa (PADes). 
Menurut Sugiyono (2016) Metode penelitian deskriptif kualitatif adalah metode penelitian yang di gunakan untuk meneliti pada kondisi objek yang alamiah, (sebagai lawannya adalah eksperimen) di mana peneliti adalah sebagai instrumen kunci, teknik pengumpulan data dilakukan secara trianggulasi (gabungan), analisis data bersifat induktif, dan hasil penelitian kualitatif lebih menekankan makna dari pada generalisasi. Objek dalam penelitian kualitatif adalah objek yang alamiah, atau natural setting, sehingga metode penelitian ini sering disebut sebagai metode naturalistic. Mengemukakan bahwa, situasi sosial untuk sampel atau instrumen sangat disarankan suatu situasi sosial didalamnya menjadi semacam muara dari banyak domain lainnya". Dalam penelitian ini teknik pemilihan informan yang dipergunakan peneliti adalah snowball sampling. Snowball sampling adalah teknik pengambilan sampel sumber data yang pada awalnya jumlahnya kecil kemudian membesar ibarat bola salju yang menggelinding yang lama-lama menjadi besar ${ }^{4}$

\section{HASIL DAN DISKUSI}

Desa Poto Tano adalah daerah yang terhampar dengan dihiasi laut dan perbukitan yang indah. Dilintasi jalan provinsi, disambungkan dengan jalan beraspal menghubungkan kabupaten satu dengan kabupaten yang lain, satu kecamatan dengan kecamatan yang lain, dan satu desa dengan desa yang lain. Desa Poto Tano terbagi dalam 3 (tiga) dusun yakni Dusun Pinamin, Dusun Poto Tano A, dan Dusun Poto Tano B serta terdiri dari 3 (tiga) Rukun Warga (RW) dan 11 (sebelas) Rukun Tetangga (RT). Mata pencaharian masyarakat Desa Poto Tano adalah sebagian besar nelayan, interaksi sosial masyarakatnya sangat harmonis dan rukun, satu sama lain saling menghargai dan menghormati sehingga tercipta lingkungan yang kondusif, aman, tentam, sejahtera dengan menjunjung tinggi nilainilai kegotongroyongan dalam membangun.

\footnotetext{
4 Pusposari, L. F., Umamah, U., \& Dwi, C. (2019). Pemberdayaan Masyarakat Berorientasi Kemandirian (Studi Pada Masyarakat Pesisir Kecamatan Camplong Kabupaten Sampang). J-PIPS (Jurnal Pendidikan Ilmu Pengetahuan Sosial), 2(1), 42-62.
} 
Desa Poto Tano mempunyai luas wilayah 2.220 ha dengan jumlah penduduk 1,239 orang. Sedangkan jumlah Kepala Keluarga 344 KK. Adapun batas wilayah Desa Poto Tano sebagai berikut:

Sebelah utara : Selat Alas

Sebelah selatan: Desa Senayan

Sebelah timur: Alas Barat

Sebelah barat: Selat Alas

Dilihat dari topografi dan kuntur tanah, Desa Poto Tano secara umum berupa laut dan perbukitan yang berada pada ketinggian antara $640 \mathrm{~s} / \mathrm{d} 700 \mathrm{~m}$ diatas permukaan laut. Dengan suhu rata-rata $22^{\circ} \mathrm{s} / \mathrm{d} 28^{\circ}$ celcius. Orbitasi dan jarak tempuh Desa Poto Tano ke ibu kota kecamatan 1,5 km, dengan waktu tempuh 15 menit dan ke ibu kota kabupaten $34 \mathrm{~km}$ dengan waktu tempuh 55 menit.

\section{Gambar 1. Peta Desa Poto Tano}

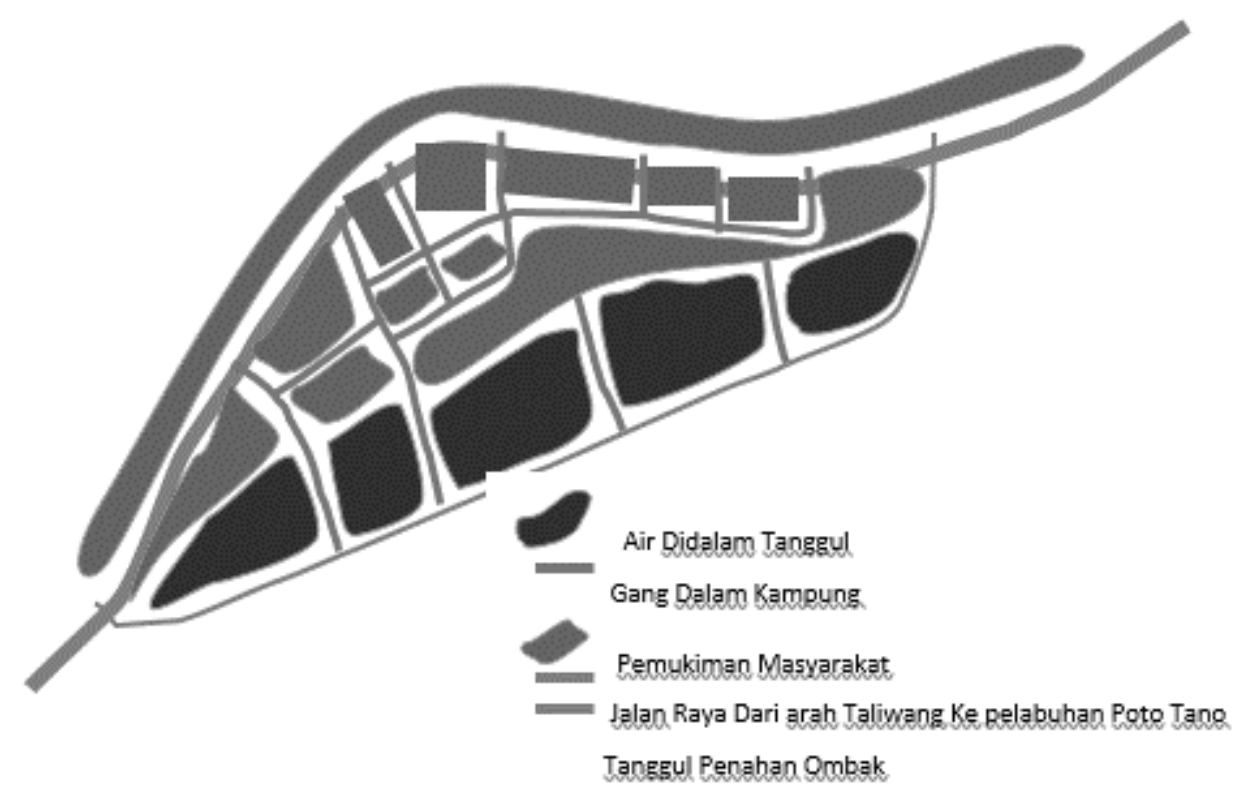

Sumber: Desa Poto Tano 
Tabel 1

Data Jumlah Penduduk Desa Poto Tano

\begin{tabular}{|l|cc|}
\hline Jumlah penduduk & 1.239 orang \\
\hline Jumlah laki-laki & $601 \quad$ orang \\
\hline Jumlah Perempuan & $638 \quad$ orang \\
\hline Jumlah Kepala Keluarga & $344 \quad$ orang \\
\hline
\end{tabular}

Sumber: Kantor Desa Poto Tano

Tabel 2.

Tingkat Pendidikan Penduduk Desa Poto Tano

\begin{tabular}{|l|l|l|}
\hline Tingkat Pendidikan & Laki-laki & Perempuan \\
\hline $\begin{array}{l}\text { Usia 3-6 Tahun yang belum masuk } \\
\text { sekolah }\end{array}$ & 11 orang & 10 orang \\
\hline $\begin{array}{l}\text { Usia 3-6 Tahun yang sedang TK atau } \\
\text { Play Group }\end{array}$ & 25 orang & 23 orang \\
\hline $\begin{array}{l}\text { Usia 7-18 Tahun yang tidak pernah } \\
\text { sekolah }\end{array}$ & - & - \\
\hline Usia 7-18 Tahun yang sedang sekolah & 89 orang & 62 orang \\
\hline $\begin{array}{l}\text { Usia 18-56 Tahun yang tidak pernah } \\
\text { sekolah }\end{array}$ & - & - \\
\hline $\begin{array}{l}\text { Usia 18-56 Tahun pernah SD tapi tidak } \\
\text { tamat }\end{array}$ & 8 orang & 11 orang \\
\hline Tamat SD Sederajat & 156 orang & 189 orang \\
\hline $\begin{array}{l}\text { Jumlah usia 12-56 tahun tidak tamat } \\
\text { SLTP }\end{array}$ & 26 orang & 23 orang \\
\hline $\begin{array}{l}\text { Jumlah usia 18-56 tahun tidak tamat } \\
\text { SLTA }\end{array}$ & 3 orang & 5 orang \\
\hline Tamat SMP sederajat & 254 orang & 289 orang \\
\hline Tamat SMA sederajat & 15 orang & 18 orang \\
\hline Tamat D1/Sederajat & - & - \\
\hline Tamat D2/Sederajat & - & - \\
\hline Tamat D3/Sederajat & - & - \\
\hline Tamat S1/Sederajat & 9 orang & 2 orang \\
\hline Tamat S2/sederajat & - & - \\
\hline Tamat S3/Sederajat & - & - \\
\hline Tamat tamat SLB A & - & - \\
\hline Tamat tamat SLB B & - & - \\
\hline Tamat tamat SLB C & $\mathbf{5 9 6}$ orang & $\mathbf{6 3 2}$ orang \\
\hline Jumlah & & \\
\hline Sumber: Kantor Desa Poto Tano & \\
\hline
\end{tabular}

Sumber: Kantor Desa Poto Tano 
Tabel 3.

Mata Pecaharian Pokok Penduduk Desa Poto Tano

\begin{tabular}{|c|c|c|}
\hline Jenis Pekerjaan & Laki-laki & Perempuan \\
\hline Petani & - & - \\
\hline Buruh tani & - & - \\
\hline Buruh migran Perempuan & - & - \\
\hline Buruh migran Laki-laki & - & - \\
\hline Pegawai Negeri Sipil & 13 orang & 3 orang \\
\hline Pengrajin Industri Rimah Tangga & - & - \\
\hline Pedagang Keliling & - & - \\
\hline Peternak & 73 orang & - \\
\hline Nelayan & 263 orang & - \\
\hline Montir & - & - \\
\hline Dokter swasta & - & - \\
\hline Bidan swasta & - & - \\
\hline Perawat swasta & - & - \\
\hline TNI & 1 orang & - \\
\hline Polri & - & - \\
\hline Pensiunan PNS/TNI/Polri & - & - \\
\hline Pengusaha kecil dan menengah & - & - \\
\hline Pengacara & - & - \\
\hline Notaris & - & - \\
\hline Dukun Kampung Terlatih & - & 1 oang \\
\hline Jasa Pengobatan Alternatif & - & - \\
\hline Dosen Swasta & - & - \\
\hline Pengusaha Besar & - & - \\
\hline Arsitektur & - & - \\
\hline Karyawan Perusahaan Swasta & 13 orang & - \\
\hline $\begin{array}{ll}\text { Karyawan } & \text { Perusahaan } \\
\text { Pemerintah } & \\
\end{array}$ & 27 orang & 6 orang \\
\hline Tukang Batu & 11 orang & - \\
\hline Pedagang & 31 orang & 29 orang \\
\hline Jumlah & 432 orang & 39 orang \\
\hline
\end{tabular}

Sumber: Kantor Desa Poto Tano

Tabel 4

Agama Penduduk Desa Poto Tano

\begin{tabular}{|l|l|l|}
\hline \multicolumn{1}{|c|}{ Agama } & \multicolumn{1}{c|}{ Laki-laki } & \multicolumn{1}{c|}{ Perempuan } \\
\hline Islam & 598 orang & 636 orang \\
\hline Kristen & - & - \\
\hline Katholik & - & - \\
\hline Hindu & 3 orang & 2 orang \\
\hline Budha & - & - \\
\hline Khonghucu & - & - \\
\hline Kepercayaan kepada YME & - & - \\
\hline Aliran kepercayaan lainya & - & - \\
\hline
\end{tabular}

Journal of Governance and Local Politics (JGLP)

ISSN (online): 2684-9992, Volume: 2, Nomor: 1, Mei 2020 


\begin{tabular}{|l|l|l|}
\hline Jumlah & 601 orang & 638 orang \\
\hline
\end{tabular}

Sumber: Kantor Desa Poto Tano

Pulau Kenawa merupakan salah satu pulau di gugusan pulau Gili Balu yang terletak di desa pesisir, Desa Poto Tano, Kecamatan Poto Tano, Kabupaten Sumbawa Barat, Provinsi Nusa Tenggara Barat. Secara geografis Pulau Kenawa terletak pada posisi $116^{\circ} 49^{\prime} 58,98^{\prime \prime}$ BT dan 08²9'55,18” LS, dengan batas wilayah administrasi sebagai berikut:

Sebelah Utara : Pulau Panjang dan Laut Flores

Sebelah Timur : Pulau Range (Namo) dan Pulau Kalong

Sebelah Selatan : Pulau Sumbawa

Sebelah Barat : Pulau Ular dan Selat Alas

Pulau Kenawa mempunyai luas 13,8 ha sedangkan garis pantai yang membentang sepanjang 1,73 km. Pulau Kenawa didominasi oleh padang rumput yang hampir lebih dari sebagian luas pulau, vegetasi mangrove menutupi sekitar $1 / 4$ garis pantai. Sedangkan tipologi pantai pada umumnya berpasir putih. Pulau Kenawa adalah pulau Sabana yang menghijau saat musim hujan dan kuning emas saat musim panas. Perpaduan alam perbukitan, hamparan pantai berpasir putih, padang rumput, serta gradasi warna air laut yang membentang, menjadikan alam Pulau Kenawa begitu indah dan mengesankan sehingga mempunyai peluang unggulan sebagai destinasi wisata alam di Indonesia 5 .

Untuk mencapai Pulau Kenawa bisa ditempuh dengan menggunakan transportasi yang menghubungkan antara Pulau Sumbawa dan Pulau Lombok, yaitu kapal feri dari Pelabuhan Kayangan di Kabupaten Lombok Timur yang menempuh 1-2 jam perjalanan mengarungi Selat Alas menuju Pelabuhan Poto Tano di Sumbawa Barat. Pelabuhan Poto Tano berada di Kabupaten Sumbawa Barat (KSB) beroprasi selama 24 jam non-stop dengan jadwal keberangkatan setiap 1 jam sekali. Poto Tano oleh masyarakat Sumbawa disebut "Lawang Desa" atau Gerbang Desa, masyarakat Sumbawa biasa menyebut Sumbawa dengan sebutan "Desa Kami” sebagai ungkapan rasa bangga dan rasa memiliki yang kuat pada tanah kelahirannya.

${ }^{5}$ Sumber data dari hasil penelitian yang dilakukan oleh Penulis Pada Tahun 2019 
Pulau Kenawa berada tidak jauh dari pelabuhan penyebrangan Poto Tano, Sumbawa Barat. Karena tidak ada kapal besar yang menyediakan jasa transportasi untuk menjangkau Pulau Kenawa, wisatawan bisa naik kapal nelayan dengan waktu tempuh sekitar 15 menit dari Pelabuhan Poto Tano.

\section{Gambar 2.}

Pulau Kenawa

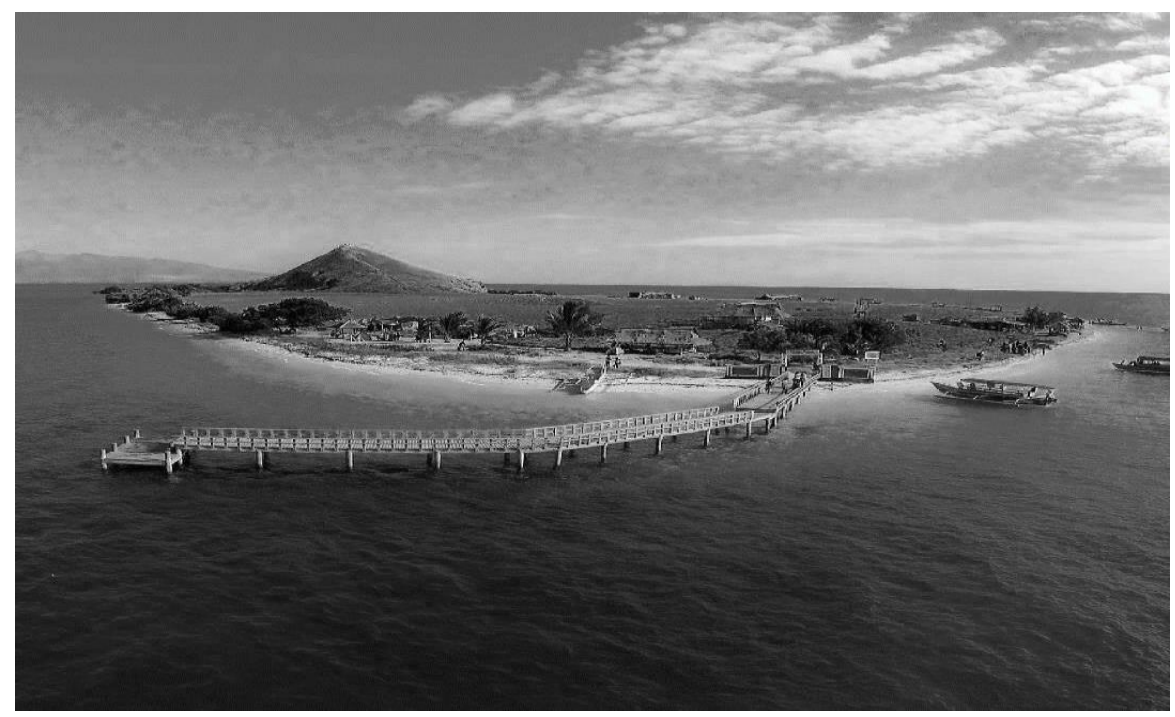

Sumber: www.wisataterindah.net

Partisipasi masyarakat dalam pengembangan potensi wisata Pulau Kenawa cukup besar, contoh partisipasi dari pemerintah desa atau masyarakat sekitar dalam pengembangan Pulau Kenawa adalah dengan ikut serta dalam semua kegiatan FGD (Focus Group Discussion) dan penyusunan rencana kerja. Dalam wawancara Bersama Bapak Anugrainsyah bahwa pengelolaan Pulau Kenawa yang merupakan salah satu dari "Gili Balu” (Delapan Pulau) yang berada di Desa Poto Tano yang telah dikerjasamakan dengan Pihak Kedua (PT. Gili Balu). Dari Pemerintah Daerah sendiri menginginkan masyarakat harus berada didepan, artinya masyarakat sekitar menjadi bagian utama dalam rencana bisnis perusahaan. Jadi yang telah dilakukan dari awal yaitu semua pelaksanaan kegiatan FGD (Focus Group Discussion) dengan masyarakat, dalam penyusunan rencana kerja juga melibatkan masyarakat. Pemerintah tentunya menginginkan masyarakat menjadi bagian penting dalam rencana bisnis perusahaan itu sendiri.

Dalam wawancara Bersama Bapak Jamaludin bahwa memang dalam perencanaan pengelolaan Pulau Kenawa kedepan dalam hal ini dari Pemerintah 
Daerah dan Pihak Kedua selalu melibatkan masyarakat dalam membahas rencana kerja, dan selama proses ini berjalan sudah enam kali melakukan kegiatan FGD (Focus Group Discussion) bersama masyarakat.

Dari penjelasan di atas sangat jelas bahwa pemerintah desa atau masyarakat sangat berpartisipasi dalam meningkatkan potensi wisata Pulau Kenawa. Dengan keikutsertaan masyarakat dalam semua kegiatan FGD (Focus Group Discussion) dan penyusunan rencana kerja menjadi suatu bukti nyata bahwa masyarakat sangat antusias dan berperan aktif dalam proses peningkatan potensi wisata Pulau Kenawa.

\section{Daya Dukung Lingkungan}

Pariwisata merupakan industri yang kelangsungan hidupnya sangat ditentukan oleh baik-buruknya lingkungan. Ia sangat peka terhadap kerusakan lingkungan, misalnya pencemaran oleh limbah domestik yang berbau dan nampak kotor, sampah yang bertumpuk, dan kerusakan pemandangan oleh penebangan hutan, serta sikap penduduk yang tidak ramah.

Tanpa lingkungan yang baik tak mungkinlah pariwisata berkembang. Karena itu pengembangan pariwisata haruslah memerhatikan terjaganya mutu lingkungan, sebab dalam industri pariwisata, lingkungan itulah yang sebenarnya dijual. Asas pengelolaan lingkungan untuk melestarikan kemampuan lingkungan dalam mendukung pembangunan yang terlanjutkan bukanlah merupakan hal yang abstrak, melainkan benar-benar konkrit dan sering mempunyai efek jangka pendek.

Daya dukung lingkungan Pulau Kenawa sangat mendukung untuk dijadikan daerah tujuan wisata, karena lingkungannya belum terlalu dieksplor yang artinya masih alami, dan didukung juga dengan tersedianya beberapa sarana dan prasarana sebagai faktor pendukung dalam pengembangan Pulau Kenawa itu sendiri.

Dalam wawancara Bersama Bapak Arif Hasyim bahwa Daya dukung lingkungan Pulau Kenawa selama ini bisa dikatakan sangat tinggi sekali karena lingkungan ini masih belum terlalu dieksplor dan masih alami. Dan sudah ada beberapa sarana dan prasarana yang telah sediakan oleh Pemerintah Daerah sebagai faktor pendukung pengembangan Pulau Kenawa tersebut. 


\section{Gambar 1.}

\section{Sarana dan Prasarana Pulau Kenawa}

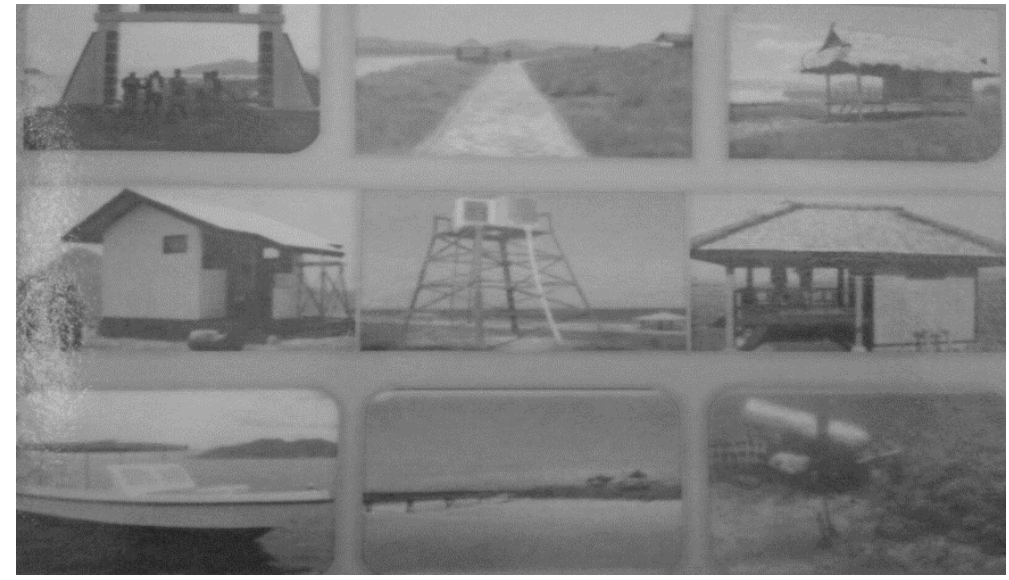

Sumber: Dinas Kelautan Dan Perikanan Sumbawa Barat

Dari penejelasan di atas sangatl jelas bahwa dukungan sarana dan prasarana dan lingkungan sudah cukup memadai untuk menjadikan Pulau Kenawa sebagai tujuan wisata. Daya dukung lingkungan pariwisata dipengaruhi oleh dua faktor utama, yaitu tujuan wisatawan dan faktor lingkungan biofisik lokasi pariwisata. Tujuan pariwisata adalah untuk mendapatkan rekreasi. Rekreasi tidak hanya berarti bersenang-senang, melainkan harus diartikan sebagai rekreasi, yaitu secara harfiah berarti diciptakan kembali. Jadi dengan rekreasi itu orang ingin menciptakan kembali atau memulihkan kekuatan dirinya, baik fisik maupun spiritual. Setelah berekreasi orang merasa dirinya pulih untuk melakukan tugasnya lagi. Karena itu tujuan rekreasi bermacam-macam, antara lain bermainmain, berolah-raga, belajar, beristirahat atau kombinasi macam-macam tujuan itu. Walaupun tujuannya bermacam-macam, tetapi semuanya mempunyai sifat umum yang sama, yaitu dilakukan di luar tugas pekerjaan untuk mendapatkan hiburan.

Dengan adanya tujuan khusus, disamping ingin mendapatkan hiburan, wisatawan tentu mengharapkan mencapai tujuan khusus itu. Harapan itu akan menciptakan suatu kondisi psikologi tertentu pada wisatawan. Karena itu daya dukung lingkungan berkaitan dengan faktor psikologi tujuan pariwisata tertentu.

\section{Promosi}

Promosi adalah langkah untuk menyebarluaskan tentang keberadaan Pulau Kenawa di Desa Poto Tano sebagai tujuan wisata kepada masyarakat luas. Promosi diharapkan mampu memberikan hasil yang lebih memuaskan dalam 
mendatangkan wisatawan lebih banyak. Dalam wawancara Bersama Bapak Roy Marhandra, Untuk promosi dari Pemerintah Desa dan dinas terkait khususnya Dinas Kebudayaan Dan Pariwisata Kabupaten Sumbawa Barat selalu melakukan promosi di setiap kesempatan, baik itu melalui media cetak, media online, serta media sosial lainnya agar supaya Pulau Kenawa ini bisa lebih dikenal oleh masyarakat luas dan bisa menarik minat wisatawan lokal dalam negeri maupun mancanegara.

Berdasarkan hasil wawancara dapat dikatakan bahwa promosi yang dilakukan oleh Pemerintah Desa sudah cukup baik, dikarenakan untuk saat ini dari Pemerintah Desa dibantu oleh Pemerintah Daerah sendiri yang bisa dilakukan hanya sebatas promosi saja sampai proses perizinan kerjasama dengan Pihak Kedua (PT. Gili Balu) selesai, karena untuk saat ini masih dalam proses perizinan.

\section{Keterlibatan Segenap Pemangku Kepentingan}

Pelaksanaan pengembangan potensi wisata Pulau Kenawa tidak bekerja sendiri. Pemerintah Desa melalui Pemerintah Daerah bekerjasama dengan Pihak Kedua (PT. Gili Balu) dan masyarakat serta dinas-dinas terkait lainnya yang merupakan bagian dari stakeholder. Pemerintah Desa ingin menjadikan Pulau Kenawa ini sebagai tujuan wisata. Untuk mengembangkan potensi wisata, sumber daya manusia merupakan hal yang penting dalam pengembangan potensi pariwisata. Demi meningkatkan potensi sumberdaya manusia, Pemerintah Daerah yang bekerjasama dengan Pihak Kedua mengadakan pelatihan-pelatihan kepada masyarakat yang tentunya untuk meningkatkan kualitas tenaga kerja lokal. Agar supaya ketika proses perizinan selesai maka tenaga kerja lokal sudah tersedia dengan sumber daya manusia yang berkualitas, jadi tidak ada alasan lagi bagi investor untuk merekrut tenaga kerja dari luar.

Dari Pemerintah Desa melalui Pemerintah Daerah sendiri dari awal mengajak Pihak Kedua untuk selalu terlibat, intinya Pemerintah Desa tidak jalan sendiri dan pihak kedua juga tidak jalan sendiri tetapi dengan melibatkan semua unsur yang terkait dalam melakukan dari perencanaan, pelaksanaan, sampai kepada evaluasi terhadap rencana bisnis selalu dilakukan bersama (Mars Anugrainsyah) 
Dari penjelasan di atas dapat disimpulkan bahwa Pemerintah Desa selalu berupaya agar dapat mejalankan kerjasama yang baik, yaitu dengan selalu melibatkan Pihak Kedua dalam menjalankan program mulai dari perencanaan, pelaksanaan, sampai kepada evaluasi terhadap rencana bisnis perusahaan.

\section{Kemitraan Kepemilikan Lokal}

Pembangunan kepariwisataan harus mampu memberikan kesempatan lapangan pekerjaan yang berkualitas untuk masyarakat setempat. Usaha fasilitas penunjang kepariwisataan seperti, cendera mata, transportasi wisata dan sebagainya seharusnya dapat dikembangkan dan dipelihara bersama masyarakat setempat melalui kerja sama yang baik. Dalam hal ini mengikutsertakan masyarakat untuk bekerja sama dalam mendukung pengelolaan pariwisata Pulau Kenawa.

Dalam wawancara bersama Bapak Ardiansyah jadi dalam hal ini ketika Pemerintah Daerah sudah bekerjasama dengan Pihak Kedua, nantinya Pihak Kedua ini akan bekerjasama lagi dengan pihak-pihak lainnya, yang utama dengan Pemerintah Desa nanti mulai dari BUMDES atau koperasi. Nantinya semua dalam pengelolaan transportasi kemudian pasokan bahan baku untuk makanan, sayur dan lain sebagainya itu harus dari perusahaan-perusahaan lokal atau lembaga yang dibentuk oleh desa.

Berdasarkan wawancara di atas dapat disimpulkan bahwa kerjasama yang dilakukan oleh Pemerintah Daerah dengan Pihak Kedua (PT. Gili Balu) sangat berdampak baik dalam hal kemitraan kepemilikan lokal dikarenakan hal tersebut akan membuat perekonomian masyarakat sekitar akan lebih baik untuk ke depannya.

\section{Pemanfaatan Sumber Daya Secara Berkelanjutan}

Pembangunan pariwisata harus dapat menggunakan sumber daya dengan berkelanjutan yang artinya kegiatan-kegiatannya harus menghindari penggunaan sumber daya yang tidak dapat diperbaharui (irreversible) secara berlebihan. Hal ini juga didukung dengan keterkaitan lokal dalam tahap perencanaan, pembangunan, dan pelaksanaan, sehingga pembagian keuntungan yang adil dapat diwujudkan. Dalam pelaksanaannya, kegiatan pariwisata harus menjamin bahwa sumber daya alam dan buatan dapat dipelihara dan diperbaiki dengan menggunakan kriteria- 
kriteria dan standar-standar internasional. Salah satu cara adalah dengan melarang para nelayan untuk melakukan pengeboman ikan dikarenakan akan merusak terumbu karang yang ada di mana Pulau Kenawa ini sesuai dengan konsepnya yaitu ekowisata, di mana terumbu karang menjadi salah satu sumber daya alam pendukung untuk pengembangan ekowisata di Pulau Kenawa tersebut.

\section{Gambar 3.}

Proses Menuju Pulau

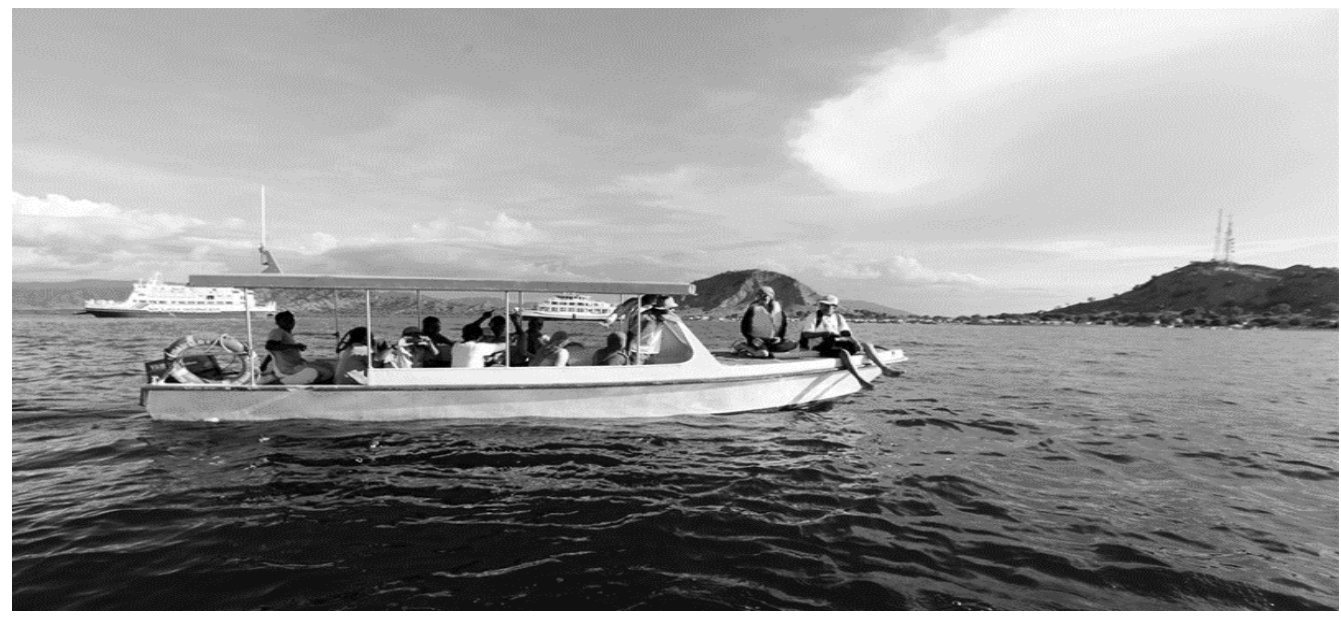

Sumber: www.wisataterindah.net

\section{Mengakomodasi Aspirasi Masyarakat}

Pariwisata pedesaan menjadi tonggak bagi perkembangan dan penguatan aktivitas kerajinan dan basis perkembangan sektor jasa sehingga di kawasan pedesaan muncul mata pencaharian yang beragam. Meskipun kemungkinan mutu pekerjaan yang ditawarkan di dalam aktivitas pariwisata tidak lebih baik dibandingkan dengan mutu pekerjaan di sektor lain namun adanya perkembangan pariwisata pedesaan mampu menambah sumber pendapatan bagi penduduk pedesaan. Dalam pengelolaan Pulau Kenawa yang berada di Desa Poto Tano, Pemerintah Daerah memfasilitasi masyarakat untuk menyampaikan usulan melalui kegiatan FGD (Focus Group Discussions).

Dalam hal ini Pemerintah Desa melalui daerah melakukan kegiatan FGD (Focus Group Discussion) sebagai bentuk fasilitasi pemerintah kepada masyarakat, dan itu sudah dilakukan dengan segmennya masing-masing. Jadi dengan nelayannya khusus melakukan pertemuan dengan pedagang, dengan wanita juga khusus melakukan pertemuan. Sehingga masing-masing segmentasi ini dapat memberikan usulan. Ketika dari pemerintah menganggap usulan itu layak untuk 
diakomodir maka kami mengharuskan perusahaan untuk mengakomodir usulan tersebut.

\section{Monitoring dan Evaluasi Program}

Kegiatan monitoring dan evaluasi program pembangunan kepariwisataan yang berlanjut mencakup mulai dari kegiatan penyusunan pedoman, evaluasi dampak kegiatan wisata serta pengembangan indikator dan batasan untuk mengukur dampak pariwisata sampai dengan pelaksanaan pemantauan dan evaluasi keseluruhan kegiatan. Monitoring dan evaluasi program baru dalam tahap perencanaan dikarnakan investasinya belum jalan, tetapi didalam aturan-aturan hukum tentang investasi ada tahapan-tahapan yang dilakukan. Jadi perusahaan wajib membuat laporan berkala, kemudian dari pihak Pemerintah Desa juga wajib melakukan investigasi rutin dan lain sebagainya. Jadi Pemerintah Desa Atau Pemerintah Daerah tetap akan mengikuti kaidah-kaidah hukum yang berlaku di dalam bidang pariwisata.

Hal ini sangatlah penting terutama untuk menjaga kualitas sarana dan prasarana serta keindahan di lokasi objek wisata, Pemeliharaan bertujuan untuk mengembangkan kepariwisataan yang berwawasan lingkungan yang sesuai dengan potensi wisata Pulau Kenawa. Jadi yang ditekankan pada awal perencanaan oleh Pemerintah Desa bahwa Pihak Kedua ini harus melakukan auditoring terhadap lingkungannya, audit ini bisa bisa dilakukan oleh auditoring pemerintah ataupun auditoring independen perusahaan. Jadi perusahaan ini merupakan perusahaan luar negeri yang memang basicnya di bidang lingkungan di ekowisata, kemungkinan mereka akan menggunakan jasa auditoring independen perusahaan untuk melakukan auditoring lingkungannya dan kemungkinan untuk masalah auditoring lingkungan pihak perusahaan sendiri akan lebih ketat dibandingkan pihak pemerintah itu sendiri.

\section{Pelatihan Pada Masyarakat}

Terkait pembangunan kepariwisataan secara berkelanjutan selalu membutuhkan pelaksanaan program-program pendidikan dan pelatihan untuk membekali pengetahuan dan keterampilan masyarakat dan meningkatkan kemampuan bisnis secara profesional. Untuk pelatihan kepada masyarakat Pemerintah Desa sudah menekankan kepada pihak perusahaan dan hal ini sudah 
dilakukan oleh pihak perusahaan. Jadi perusahaan wajib membekali masyarakat sekitar dengan skill yang dibutuhkan pada masing-masing bidang, misalnya pelatihan bahasa inggris, pelatihan diving, snorkeling itu wajib, kemudian kebutuhan tenaga kerja di villa misalnya, pelatihan untuk bartender, cleaning service, dan sebagainya itu sudah dilatih semua.

Pelatihan SDM yaitu tentang pelayanan prima. Kesiapan produk yang memadai tidak dapat berjalan dengan baik tanpa adanya pelayanan prima dari masyarakat pelaku wisata. Masyarakat diberi pelatihan tentang cara melayani wisatawan yang datang ke Pulau Kenawa, hal ini disampaikan agar wisatawan yang datang tidak kecewa dengan pelayanan yang ada dan tidak akan kembali lagi. Pada presentasi menjalaskan tantang; Konsep pelayanan prima, unsur layanan, sikap mental pelayanan prima, kepuasaan semua ini akan membuat masyarakat menjadi termotivasi untuk kemajuan wisata Pulau Kenawa.

Dari penjelasan di atas membuktikan bahwa Pemerintah Desa memang serius, sehingga dari awal Pemerintah Desa sudah menekankan kepada pihak perusahaan untuk membekali masyarakat sekitar dengan skill yang dibutuhkan di masing-masing bidang dengan memberikan pelatihan-pelatihan kepada masyarakat. Harapan Pemerintah Desa sendiri agar supaya ketika peroses perizinan sudah selesai maka tidak ada lagi alasan pihak perusahaan untuk merekrut tenaga kerja dari luar dikarenakan tenaga kerja lokal sudah tersedia dengan sumber daya manusia yang berkualitas.

Jadi peran Pemerintah Desa atau Pemerintah Daerah dalam mengoptimalisasikan potensi wisata di Pulau Kenawa untuk saat ini masih belum adanya aktivitas pengelolaan dikarenakan investasi belum berjalan dan itu disebabkan karena proses perizinan kerjasama antara Pemerintah Daerah dengan Pihak Kedua (PT. Gili Balu) belum selesai, di mana proses perizinan ini sudah berlangsung cukup panjang yang menghabiskan waku sekitar empat tahun proses perizinan itu berlangsung, dan dari pihak Pemerintah Daerah sendiri akan mengusahakan untuk bisa menyelesaikan proses perizinannya tahun 2020 ini agar supaya bisa secepatnya untuk melaksanakan aktivitas pengelolaan di Pulau Kenawa tersebut. 
Apabila ditinjau dari sarana dan prasarananya untuk saat ini sudah ada sebagian sarana dan prasarana yang di bangun oleh pemerintah yaitu seperti beruga, toilet, tampungan air, dan lain sebagainya, akan tetapi masih kurang terawat, ada beberapa yang sudah rusak dan bisa dikatakan sudah tidak layak untuk digunakan. Untuk melakukan penarikan pajak guna meningkatkan Pendapatan Asli Desa (PADes) saat ini juga masih belum bisa dikarnakan tidak adanya aturan sebagai dasar untuk melakukan penarikan, contohnya seperti parkir, penambang kapal untuk penyebrangan itu merupakan pendapatan pribadi dan tidak ada potongan untuk pajak, jadi untuk rencana kedepannya setelah proses perizinannya selesai dan investasi sudah berjalan Pemerintah Daerah akan membuat berupa Perda atau Perdes agar mempunyai dasar untuk melakukan penarikan dan apabila sudah ada aturan yang mengatur dan dapat berjalan dengan efektif maka berpotensi akan berdampak baik terhadap peningkatan Pendapatan Asli Desa (PADes).

Perlu diketahui juga bahwa Pulau Kenawa status lahannya merupakan kawasan hutan, dalam hal ini maka kewenangan atas segala penempatannya ada di Kementerian Lingkungan Hidup dan Kehutanan (LHK), akan tetapi dari pihak Pemerintah Daerah sendiri menginginkan keberadaan Pulau Kenawa memberikan hasil atau manfaat untuk masyarakat dan pemerintah desa, maka dari pihak Pemerintah Daerah sendiri menjalankan mekanisme perizinan, jadi nama izinnya yaitu usaha pemanfaatan jasa lingkungan kalau di kawasan hutan.

Sampai saat ini masih belum adanya aktivitas pengelolaan di Pulau Kenawa dikarenakan proses perizinan kerjasama antara Pemerintah Daerah dengan Pihak Kedua (PT. Gili Balu) masih belum selsesai, jadi untuk hambatan awal yang dihadapi saat ini yaitu hambatan perizinan, di mana proses perizinan kerjasama ini sudah berlangsung selama empat tahun, dan Pemerintah Daerah sendiri akan mengusahakan izin kerjasama dengan Pihak Kedua ditargetkan selesai pada tahun 2020 ini agar supaya secepatnya aktivitas pengelolaan berjalan.

Apabila ditinjau dari sumber daya alam pastinya sangat mendukung sekali, karena sumber daya alam yang terdapat di kawasan Pulau Kenawa sendiri sangat kaya akan potensi wisata, hanya tinggal menunggu sentuhan pengelolaannya saja, begitu pula dengan sumber daya manusianya, masyarakat sendiri sudah mengikuti 
kegiatan pelatihan-pelatihan yang diadakan oleh perusahaan yang sesuai dengan bidangnya masing-masing, sehingga untuk tenaga kerja lokal sudah sangat tersedia dengan sumber daya manusia yang berkualitas. Lalu untuk masalah anggaran, saat ini sudah ada investor yang mau dan serius untuk mengelola Pulau Kenawa itu sendiri yaitu Pihak Kedua (PT. Gili Balu). Beberapa faktor tersebut merupakan bagian dari faktor pendukung untuk mengoptimalkan pengelolaan Pulau Kenawa. Jadi untuk saat ini kendala utamanya yaitu diproses perizinan yang cukup panjang ini, hal ini terjadi juga salah satu faktornya adalah penarikan kewenangan dari Pemerintah Kabupaten ke Pemerintah Provinsi.

\section{KESIMPULAN}

Hal ini menjadi tantangan bagi pengembangan pembangunan di segala sektor wilayah Desa Poto Tano, oleh sebab itu segala potensi yang ada tentunya harus dioptimalkan agar Desa Poto Tano menjadi desa yang mandiri dan dapat mewujudkan otonomi desa sebagaimana yang diamanatkan dalam UU No. 6 Tahun 2014. Berdasarkan penelitian yang dilakukan, Pemerintah Desa selalu menetapkan strategi agar saling berkoordinasi dengan semua pelaku terutama pngelola dan pihak Pemerintah Desa serta BPD. Dengan koordinasi dan kerjasama yang baik maka tujuan untuk dapat meningkatkan perekonomian Desa dapat dilakukan dengan teratur dan terstruktur pada masing-masing pengelolaannya. Masyarakat sangat berpartisipasi dalam meningkatkan potensi wisata Pulau Kenawa. Dengan keikutsertaan masyarakat dalam semua kegiatan FGD (Focus Group Discussion) dan penyusunan rencana kerja menjadi suatu bukti nyata bahwa masyarakat sangat antusias dan berperan aktif dalam proses peningkatan potensi wisata Pulau Kenawa.

Daya dukung lingkungan Pulau Kenawa sangat mendukung untuk dijadikan daerah tujuan wisata, karena lingkungannya belum terlalu dieksplor yang artinya masih alami, dan didukung juga dengan tersedianya beberapa sarana dan prasarana sebagai faktor pendukung dalam pengembangan Pulau. Untuk promosi dari Pemerintah Daerah sendiri khususnya Dinas Kebudayaan Dan Pariwisata Kabupaten Sumbawa Barat selalu melakukan promosi di setiap kesempatan, baik itu melalui media cetak, media online, serta media sosial lainnya agar supaya Pulau 
Kenawa bisa lebih dikenal oleh masyarakat luas dan bisa menarik minat wisatawan lokal maupun mancanegara.

Untuk saat ini dalam hal monitoring dan evaluasi program dari pihak Pemerintah Desa belum dilakukan dikarenakan investasinya belum jalan, monitoring dan evaluasi program masih dalam tahap perencanaan sampai investasinya sudah berjalan, akan tetapi untuk saat ini Pemerintah tetap mengikuti kaidah-kaidah hukum yang berlaku di bidang pariwisata, contohnya perusahaan wajib membuat laporan berkala, kemudian dari pihak Pemerintah Daerah sendiri juga wajib melakukan investigasi rutin dan lain sebagainya.

Sampai saat ini masih belum adanya aktivitas pengelolaan di Pulau Kenawa dikarenakan proses perizinan kerjasama antara Pemerintah Daerah dengan Pihak Kedua (PT. Gili Balu) masih belum selsesai, jadi untuk hambatan awal yang dihadapi saat ini yaitu hambatan perizinan. Proses perizinan kerjasama ini sudah berlangsung selama empat tahun, dan Pemerintah Daerah sendiri akan mengusahakan izin kerjasama dengan Pihak Kedua ditargetkan selesai pada tahun 2020 ini agar supaya secepatnya aktivitas pengelolaan berjalan.

\section{REFRENSI}

Amil, A., Maniza, L. H., \& Wahyudi, R. (2019). Peran Pemerintah Desa Poto Tano Terhadap Pengembangan Objek Wisata Pulau Kenawa Dalam Membangun Ekonomi Masyarakat. JIAP (Jurnal Ilmu Administrasi Publik), 7(2), 167-181.

Andari, I. G. A. R. D., Sulindawati, N. L. G. E., Atmadja, A. T., \& SE, A. (2017). Optimalisasi Pengelolaan Pendapatan Asli Desa Untuk Meningkatkan Pembangunan Perekonomian Desa Pada Desa Pejarakan, Kecamatan Gerokgak, Kabupaten Buleleng. JIMAT (Jurnal Ilmiah Mahasiswa Akuntansi) Undiksha, 7(1).

Badrudin, Rudy. (2015). Ekonomika Otonomi Daerah, UPP STIM YKPN: Yogyakarta.

Deritasari, Mahadika Tegar \& Untung Dwi Hananto, Indarja. (2014). Upaya Peningkatan Pendapatan Asli Daerah Melalui Sektor Pariwisata Di Kabupaten Banjar negara", http://ejournal-s1.undip.ac.id/index.php/dlr Volume 3, Nomor 2. 
Efendi. (2014.) Kewenangan Pengelolaan Sumber Daya Alam Pada Era Otonomi Khusus Di Aceh. Yustisia Vol. 3 No. 2

Kasih, Y., Kasih, Y., Widagdo, H., \& Pratiwi, R. (2017, August). Pemberdayaan Pelaku Usaha Tahu Rumahan Di Kabupaten Banyuasin Sumatera Selatan. In Prosiding Seminar Nasional Pengabdian Kepada Masyarakat. Lembaga Penelitian dan Pengabdian Kepada Masyarakat Universitas Muhammadiyah Palembang.

Muh. Aris Marfai, \& Widodo. Moralitas lingkungan: refleksi kritis atas krisis lingkungan berkelanjutan. Wahana Hijau (WeHa): Kreasi Wacana.

Nursetyasari, R. R. D., \& Sujali, S. (2012). Daya Saing Kampung Wisata Dipowinatan Kota YOGYAKARTA. Jurnal Bumi Indonesia, 1(2).

Sunaryo, Bambang. (2013). Kebijakan Pembangunan Destinasi Pariwisata Konsep dan Aplikasinya Indonesia. Yogyakarta: Gava Media.

Pulungan, M. Soleh. (2013.) Optimalisasi Pengembangan Potensi Ekowisata Sebagai Objek Wisata Andalan Di Kabupaten Kutai Kartanegara Provinsi Kalimantan Timur", Jurnal Bina Praja/Volume 5 Nomor 3 : 205-214.

Sugiyono. (2016a). Memahami Penelitian Kualitatif. Cetakan ke-11, Bandung: Alfabeta.

Sugiyono. (2016b). Metode Penelitian Kuantitatif dan Kualitatif, dan R\&D, Cetakan ke-26. Bandung: Alfabeta.

Undang-Undang Republik Indonesia Nomor 10 Tentang Kepariwisataan Tahun 2009

Undang-Undang Republik Indonesia Nomor 33 Tentang Perimbangan Pemerintah Pusat Dan Pemerintah Daerah Tahun 2004

Undang-Undang Tentang Pemeriintah Daerah, UU Nomor 23 Tahun ,2014 LN No. 244, TLN. No. 5587, Psl. 285

Wawancara bersama bapak Anugrainsyah selaku Kepala Bidang Ekonomi BAPPEDA Kabupaten Sumbawa Barat, Senin Pukul 09.22 Wita.

Wawancara bersama bapak Jamaludin selaku Masyarakat Desa Poto Tano, Senin Pukul 11.22 Wita. 
Wawancara bersama bapak Arif Hasyim selaku Koordinator Kelautan Dan Perikanan

Dinas Kelautan Dan Perikanan Kabupaten Sumbawa Barat, Rabu Pukul 10.23 Wita.

Wawancara bersama bapak Roy Marhandra selaku Kasi Objek Dan Sarana Wisata Dinas Kebudayaan Dan Pariwisata Kabupaten Sumbawa Barat, Rabu Pukul 11.34 Wita.

Wawancara bersama bapak Ardiansyah selaku Kasi Pemerintahan Kantor Desa Poto Tano, Senin, 10.43 Wita. 